\title{
Foraging of the green sea turtle Chelonia mydas on seagrass beds at Mayotte Island (Indian Ocean), determined by acoustic transmitters
}

\author{
Coralie Taquet $^{1,2, *}$, Marc Taquet ${ }^{1}$, Tim Dempster ${ }^{3}$, Marc Soria $^{4}{ }_{\text {, Stéphane Ciccione }}^{5}$, \\ David Roos ${ }^{1}$, Laurent Dagorn ${ }^{6}$
}

\footnotetext{
${ }^{1}$ Institut Français de Recherche pour l'Exploitation de la Mer (IFREMER), rue Jean Bertho, BP 60, 97822 Le Port Cedex, France ${ }^{2}$ Institut National Agronomique de Paris-Grignon (INA P-G), 16 rue Claude Bernard, 75005 Paris 5ème, France ${ }^{3}$ SINTEF Fisheries and Aquaculture, 7465 Trondheim, Norway

${ }^{4}$ Institut de Recherche pour le Développement (IRD), Campus Universitaire du Moufia, BP 172, 97492 Sainte-Clotilde Cedex, France

${ }^{5}$ Centre d'Etude et de Découverte des Tortues Marines (CEDTM), BP 40, 97898 Saint Leu Cedex, France

${ }^{6}$ Institut de Recherche pour le Développement (IRD), BP 570, Victoria, Mahé, Seychelles
}

\begin{abstract}
We studied the foraging rhythms of green sea turtles Chelonia mydas on the seagrass beds of N'Gouja Bay, Mayotte Island (Comoros Archipelago) with acoustic transmitters and moored listening stations. We monitored 8 tagged turtles (4 probable males, 3 probable females and 1 immature), from 70 to $109 \mathrm{~cm}$ curved carapace length (CCL), for durations ranging from 5 to $92 \mathrm{~d}$. The turtles exhibited a regular diel pattern: they foraged mainly during the day (on average $87 \%$ of seagrass detections were between 06:00 and 18:00 h) and rested on the inner reef slope during the night. Night time feeding activities were observed on the seagrass bed when the night light was high. The presence of turtles on the seagrass bed at night was significantly correlated with a night light index ( $r=0.54, p=0.002)$, which included both moon light and cloudiness indices. Behaviour of the only immature individual observed was similar to adult turtles, although it rested more frequently around noon. All turtles displayed a high fidelity to 1 foraging site within the seagrass bed. Acoustic transmitters and permanent listening stations are an appropriate technique for long-term behavioural studies of turtles, with no human interaction with turtles during tracking, and represent a suitable technique to assess the possible effects of environmental changes or human activities upon green turtle behaviour.
\end{abstract}

KEY WORDS: Chelonia mydas $\cdot$ Southwestern Indian Ocean $\cdot$ Mayotte $\cdot$ Green sea turtle $\cdot$ Acoustic transmitter $\cdot$ Listening station $\cdot$ Foraging rhythm

\section{INTRODUCTION}

Due to overexploitation of eggs and adults on nesting beaches, negative interactions with fisheries, and alterations in both nesting and feeding habitats, the green sea turtle Chelonia mydas is endangered (IUCN Red List, Seminoff 2004). Studies have sought to gather biological information to develop appropriate conservation measures. Most investigations of green sea turtles in the southwestern Indian Ocean have focused on adults during their reproductive phase. These studies dealt mainly with female population abundance near the principal nesting sites, reproductive parameters, behaviours related to nesting activities, and breeding migrations (Le Gall et al. 1985, 1986, Le Gall \& Hughes 1987, Pelletier et al. 2003). However, the foraging behaviour of green sea turtles in this area remains poorly understood.

Green turtles in the southwestern Indian Ocean feed on shallow coastal seagrass beds (Bjorndal 1997), which are often accessed by humans. The following 3 types of foraging sites can be identified: (1) sites where seagrass beds are dominant, (2) sites where algae are dominant, and (3) mixed seagrass and algae sites. Usu- 
ally, foraging grounds are bays composed of seagrass and/or algae patches. Stands of coral reef (resting zones) can occur nearby, interspersed with the patches of seagrass, or be located more distant from the seagrass bed. Studying green turtle foraging behaviour in such coastal areas has become a priority in order to define conservation measures to protect green sea turtles. Determining when turtles forage, for how long, and the possible effects of environmental factors on foraging behaviour, is of primary importance.

Within the Mozambique channel area, Mayotte Island is an exceptional site for studying green turtles as it comprises numerous nesting beaches (Frazier 1985) and extensive seagrass beds (Guerniou \& Nicet 2001), and is close to other nesting sites in the region: Mohéli (Comoros Archipelago), Europa, Glorieuses, Tromelin (named 'îles Eparses françaises') and Madagascar. N'Gouja Bay, located on the south coast of Mayotte, is a small Marine Protected Area (MPA). In this bay, the seagrass bed is accessible from the coral reef, and the underwater topography enables the foraging grounds (seagrass bed) and resting areas (inner reef slope) to be clearly distinguished.

A variety of electronic transmitters and tracking techniques have been used to study the behaviour of green turtles over the past 2 decades. Satellite tracking has been frequently used to study long-distance migratory movements between nesting and foraging sites (Luschi et al. 1998, Cheng 2000, Godley et al. 2002, Pelletier et al. 2003); however, this technique is not appropriate for studying the fine-scale behaviour of turtles within a restricted area such as N'Gouja Bay. Studies investigating movements in foraging, resting and nesting areas over smaller spatial scales have used radio telemetry (Dizon \& Balazs 1982, Whiting \& Miller 1998), or sonic telemetry in real time using a small boat equipped with direc-

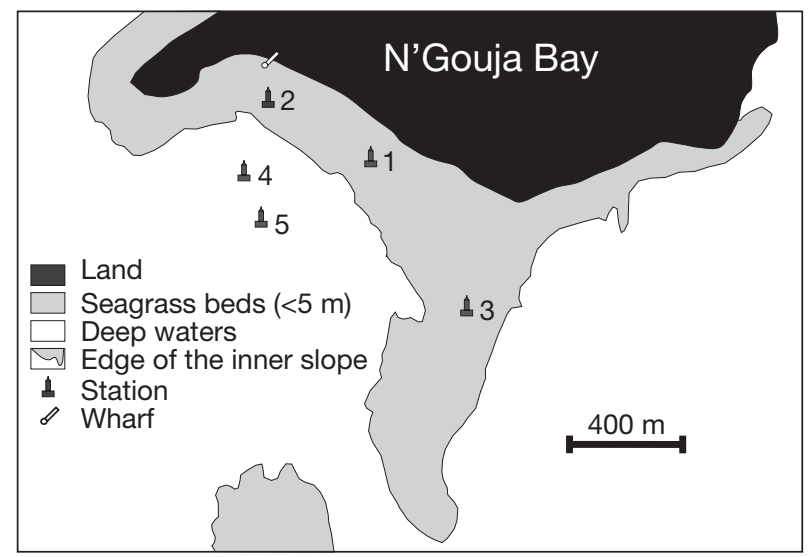

Fig. 1. Map of N'Gouja Bay, Mayotte, with the positions of the listening stations $(\Perp)$. Stns 1 to 3 are within the seagrass bed; Stns 4 and 5 are positioned offshore. Wharf near Stn 2 indicates location on the beach where turtles were tagged tional hydrophones (Ireland 1981, Mendonca 1983, Odgen et al. 1983, Brill et al. 1995, Seminoff et al. 2002). In order to study the foraging rhythms of green turtles, we equipped 8 individuals with acoustic transmitters and passively tracked them using a network of listening stations moored in N'Gouja Bay, Mayotte. The monitoring network enabled us to observe how turtles used a small foraging area over several weeks to months. To our knowledge, this is the first time this technique has been applied to sea turtles.

\section{MATERIALS AND METHODS}

N'Gouja Bay study site. The seagrass bed in N'Gouja Bay is L-shaped (Fig. 1) and 140 ha in size. A band of seagrass approximately $1.4 \mathrm{~km}$ long and $200 \mathrm{~m}$ wide skirts the beach, and a further section in the southern part of the bay (approximately $1.2 \mathrm{~km}$ long and $400 \mathrm{~m}$ wide) is located perpendicular to the shore. The seagrass bed lies near the low water level, and therefore it almost emerges during very low tides. In the middle part of the seagrass bed (halfway between the beach and the rocky inner slope), the level of immersion varied between 0.09 and $3.54 \mathrm{~m}$ during the study. Fig. 1 was drawn after an aerial photo (Institut Géographique National; IGN) using MapInfo software.

In front of the beach, the beds are composed of pluri-specific, close-cropped seagrass with some sandy patches. Seagrass density increases with increasing distance from the beach (Guerniou \& Nicet 2001). The seagrass species present are predominantly Cymodocae sp., Halodule sp. and Syringodium isoetifolium, with scarce patches of Halophila ovalis. Most of these species are consumed by green sea turtles in the Indian Ocean (Bjorndal 1997). Some patches of algae, mainly Padina sp. and Dictyota sp., were also present on the rocky area close to the reef inner slope (Guerniou \& Nicet 2001). Closer to the inner reef slope, corals become increasingly abundant and gradually replace the seagrass. The dominant species of algae in this area are Dictyota sp. and Padina sp. Adult green turtle diets are typically composed of seagrass species or algae species, with mixed diets less frequent due to gut specialization (Bjorndal et al. 1991, Bjorndal 1997). Green turtles in the Indian Ocean are known to have a seagrass diet (Bjorndal 1997), and the only 3 autopsies carried out on green turtles at Mayotte showed no algae in the stomach (S. Ciccione unpubl. data).

Visual observations. Underwater observations were performed before and during the turtle tracking period in order to better understand both the site configuration and the general behaviour of turtles in the area. Visual observations of turtles were made (1) on the seagrass bed by snorkelling and (2) on the inner slope by 
SCUBA diving. We carried out 5 visual trackings and 40 'transects' on the seagrass bed. During trackings, the observer focused on 1 individual (Focal Scan Sampling, Altmann 1974), and noted the time and duration of each activity over $1 \mathrm{~h}$. During a transect of 30 min duration and approximately $400 \mathrm{~m}$ length, turtles were counted and their activity noted (Instantaneous Scan Sampling, Altmann 1974). During observations we kept a minimum distance of $4 \mathrm{~m}$ between the observer and the turtle in order to avoid disturbing the animal. Approaches to determine if the turtle was tagged were made with slow movements to minimize disturbance. We recorded 4 possible behaviours: foraging, breathing, displacement (swimming) and resting. Night time SCUBA diving observations (10 dives over a 2 mo period) were conducted before the experiment to record turtle activities on the inner slope. Behaviours were recorded as for the seagrass bed.

Movements of individual turtles. To track turtle movements, we used Vemco (Shad Bay) V16-5H-R04K transmitters that randomly emitted 1 signal every 60 to $183 \mathrm{~s}$ to avoid collisions between signals coming from different transmitters. This technique enabled tracking of several turtles on the same frequency $(69 \mathrm{kHz})$. Vemco VR2 listening stations were used to collect data from the transmitters. To hold the listening stations in fixed positions on the seafloor, anchored bases consisting of tyres filled with concrete were built. A PVC flange was embedded in the middle of the base, allowing the fixation of a PVC tube $(10 \mathrm{~cm}$ diameter, $70 \mathrm{~cm}$ high) that contained and protected the listening station. For each detection that was properly received, the listening stations recorded the ID number of the turtle, the date and the time of day. Data were retrieved from the receiver twice during the 3 mo study period, using a computer system interface and Vemco VR2-PC software.

The acoustic detection range of a listening station depends on the frequency and power of the transmitters, the location of obstacles such as rocks, and on environmental conditions (e.g. water turbidity, water depth, sea state, environmental noise). The usual range of detection for V16 transmitters by VR2 listening stations in open oceanic waters is on average greater than $600 \mathrm{~m}$ (Taquet 2004). In situ tests carried out with an active transmitter indicated an average maximum detection range of transmitters by listening stations of $200 \mathrm{~m}$. This range was used to position the listening stations to optimize the detection of tagged turtles in the feeding area (seagrass bed) and the resting area (reef slope) without overlapping between the 2 zones.

Listening Stns 1, 2 and 3 were positioned $400 \mathrm{~m}$ from each other (Fig. 1). They covered the most important part of the seagrass bed without overlapping, and their positions ensured that turtles in resting positions beyond the inner slope (in waters deeper than $10 \mathrm{~m}$ ) could not be detected by these stations. We verified this by in situ tests with active transmitters. For this last condition, the site topography was advantageous because the inner slope was very steep. The offshore stations (Stns 4 and 5) were positioned on the bottom at $30 \mathrm{~m}$ depth, $200 \mathrm{~m}$ from each other and $200 \mathrm{~m}$ off the seagrass bed. In these positions, the offshore stations covered the maximum area of the inner slope zone that bordered the studied seagrass zone covered by Stns 1 and 2. The detection limits of the offshore stations reached the inner slope, without overstepping it. This portion of the inner slope (in front of Stns 1 and 2) corresponded to the area where most of the turtles resting on the inner slope were observed during diving. Such a spatial configuration resulted in some overlap between the 2 offshore stations. This overlap was necessary to maximize our chances of detecting turtles when they rested on the inner slope, which was the purpose of these stations.

The tagging procedure was carried out on the beach near the wharf (Fig. 1). To minimize stress, each turtle was caught close to the tagging station by free divers, brought back carefully to the beach and tagged. The V16 transmitter was fixed quickly to the ventral posterior part of the carapace with silicone glue and 2 Colson brackets after Seminoff et al. (2002). All turtles were then released on the seagrass bed just in front of the tagging site. Eight turtles were tagged (Table 1): 4 probable males, 3 probable females and 1 immature. Over the $10 \mathrm{yr}$ of nesting beach surveys on Mayotte Island, the smallest nesting green turtle observed was $82 \mathrm{~cm}$ CCL (S. Ciccione unpubl. data). We therefore assumed that a green turtle with a CCL greater than $82 \mathrm{~cm}$ that did not have an elongated tail was a probable female. Every turtle smaller than $82 \mathrm{~cm}$ CCL was then considered as an immature. Each turtle was double tagged with a stainless steel conventional tag (Moneltag, National Band

Table 1. Chelonia mydas. Turtle sex, size and duration of acoustic tracking at N'Gouja Bay. M: probable male, F: probable female, I: immature, CCL: curved carapace length. Dates given as $\mathrm{dd} / \mathrm{mm}$

\begin{tabular}{|lrrrrrl|}
\hline Turtle Sex CCL & $\begin{array}{c}\text { Survey } \\
\text { start } \\
\text { date } \\
2003\end{array}$ & $\begin{array}{c}\text { Survey } \\
\text { end } \\
\text { date } \\
2003\end{array}$ & $\begin{array}{c}\text { Survey } \\
\text { duration } \\
\text { (d) }\end{array}$ & $\begin{array}{c}\text { Observations } \\
\text { and } \\
\text { hypotheses }\end{array}$ \\
\hline 1 & & & & & & \\
\hline 2 & $\mathrm{M}$ & 109 & $11 / 06$ & $22 / 07$ & 42 & Site departure \\
3 & $\mathrm{~F}$ & 99 & $11 / 06$ & $15 / 06$ & 5 & Transmitter loss \\
4 & $\mathrm{~F}$ & 102 & $14 / 06$ & $27 / 08$ & 75 & Transmitter loss \\
5 & $\mathrm{I}$ & 70 & $13 / 06$ & $09 / 09$ & 88 & End of study \\
6 & $\mathrm{~F}$ & 98 & $14 / 06$ & $29 / 07$ & 46 & Site departure \\
7 & $\mathrm{M}$ & 95 & $13 / 06$ & $07 / 07$ & 25 & Transmitter loss \\
8 & $\mathrm{M}$ & 92 & $9 / 06$ & $09 / 09$ & 92 & End of study \\
\hline
\end{tabular}


and Tag) on the right fore flipper so turtles that lost their transmitters could be identified.

Analyses of foraging and resting behaviour. Turtles 2 and 3 were removed from the analysis of foraging behaviour because they lost their transmitters 5 and $6 \mathrm{~d}$ after tagging, respectively. The present study recorded data over a maximum of $92 \mathrm{~d}$. To analyse movements between foraging and resting zones, we restricted data to the period from June 14 to July 14, 2003 (31 d). Detections by Stns 1, 2 and 3 were pooled together as they represent presence of turtles on the seagrass bed, and detections by Stns 4 and 5 were pooled together as an indication of presence of turtles at the offshore area. For each turtle, we summed the numbers of detections in each category (seagrass bed and offshore areas) for each hour of the day during this period. To compare turtle presence on the seagrass bed between day and night hours, we performed an exact permutation test (paired samples) with StatXact software. To estimate how much time each turtle was detected or not during the study, we performed another analysis. A transmitter emitted a signal every 60 to $183 \mathrm{~s}$, so on average every $121.5 \mathrm{~s}$. We then calculated the expected total number of detections for each turtle, assuming that the turtle would always have been in the detection zone of 1 of the 5 stations and that transmitter detection was perfect. It was calculated for each hour of the day: $(31 \mathrm{~d} \times 60 \mathrm{~min} \times 60 \mathrm{~s}) / 121.5 \mathrm{~s}^{-1}=919$ detections $\mathrm{h}^{-1}$ for a survey of $31 \mathrm{~d}$. This theoretical total number of possible detections was then used to calculate the percentage of detections actually received, by dividing the actual number of detections for seagrass and offshore stations by the theoretical total.

Proportions of detections made by each of the 3 seagrass stations were calculated to determine the fidelity of turtles to particular foraging zones. When we analysed detections at the 2 offshore stations to determine the fidelity of individual turtles to particular resting zones, occasions when detections of the same tag were made by both offshore stations at the same time (due to overlapping) were removed. They represented between 6 and $33 \%$ of offshore detections, depending on the turtle.

Influence of tides on signal reception by seagrass bed listening stations. Mayotte is subject to semidiurnal tides. The listening stations were $70 \mathrm{~cm}$ above the bottom and the positions of listening stations on the seagrass beds were $26 \mathrm{~cm}$ above the low tide level; if the tide level dropped below $96 \mathrm{~cm}$ (which often occurs at Mayotte), the listening stations emerged from the water and were inoperative, even though turtles could be on the seagrass bed. To estimate the effect of large tides on the number of detections, we determined whether stations were submerged or emerged for each 10 min period during the study. For each $10 \mathrm{~min}$ period, if the tidal level was less than $96 \mathrm{~cm}$ (e.g. listen- ing station emerged), this 10 min period was termed an emergence period. Using this method we estimated an hourly emergence rate according to the time of day.

Influence of night light on foraging behaviour. To determine the effect of night light on foraging rhythms, we analysed the movements of turtles (the number of detections collected) at night for the $31 \mathrm{~d}$ period with respect to a night light index. Moon light intensity was calculated with 'LunarPhase' software as a percentage of the maximum moon light intensity. A cloudiness index was obtained from the Météo-France-Réunion agency as the proportion of the sky (between 1/8 and $8 / 8$ ) that was cloudless. We converted these values into percentages. If $x \%$ of the sky was clear and cloudless, and if the moon emitted $y \%$ of its maximum light intensity, then the night light index was $x y \%$ of the maximum night light intensity. This night light index was calculated for each night of the study period. We tested for a correlation between the night light index and the total number of detections per turtle at night with SPSS software (linear regression).

\section{RESULTS}

\section{Detection of transmitters by listening stations}

Of the 8 tagged turtles, only 2 (Turtles 5 and 8) were still detected by the listening stations at the end of the observation period (durations of 88 and $92 \mathrm{~d}$, respectively), while tracking of the 6 others stopped before the end of the observation, with durations ranging from 5 to $75 \mathrm{~d}$ (Table 1). Turtle 1 was detected by the listening stations until 22 July 2003 (Day 42). Turtle 1 either left N'Gouja Bay, lost its transmitter outside the detection zone, or its transmitter failed on this exact date. Turtles 2 and 7 were visually observed on the seagrass bed and identified by their conventional tags, without their transmitters. The transmitter of Turtle 2 was continuously detected by the offshore stations (and not by the seagrass bed stations) from 15 June 2003 (Day 5), which indicates that transmitter loss occurred on this day. The transmitter of Turtle 4 was recovered on the bottom on the inner slope by a diver. Turtle 3 had a similar detection pattern to Turtle 2, and seemed to have lost its transmitter on 16 June 2003 (Day 6). From 2 August 2003 (Day 55) to 15 August 2003 (Day 68), Turtle 8 was only detected by Stn 5, and it was not detected by any station thereafter until 25 August 2003 (Day 78). It was then detected regularly by the offshore stations, generally around 00:00 h, but never by the stations on the seagrass bed. We assume that Turtle 8 left the offshore region N'Gouja bay for $10 \mathrm{~d}$ (from 15 to 25 August 2003) and returned, never moving over the seagrass bed. 


\section{Movements of the turtles}

The number of detections received varied greatly among stations (Table 2). Stn 2 recorded the vast majority of all detections by the seagrass bed stations (between 84 and $98 \%$, depending on the turtle). Only 3 of the tagged turtles were detected by Stn 3 and only on very rare occasions. Turtle 6 alone represented $55 \%$ of all detections recorded by this station. All turtles were detected by the 2 offshore stations. While Turtle 1 was more or less evenly detected by Stns 4 and 5, Turtles 5, 6 and 7 were mainly detected by Stn 4 , and Turtles 4 and 8 were mainly detected by Stn 5 (Table 2).

The visual trackings and transects showed that when turtles were located on the seagrass bed, they were feeding for $95 \%$ of the time, the remainder being devoted to slow movements $(4 \%)$ and surface breathing $(<1 \%)$. When they were observed outside the seagrass bed, mainly in coral caves on the inner slope, turtles were resting for $98 \%$ of the time. These results enabled us to assume that detection of a turtle by a listening station on the seagrass bed is representative of feeding, and that detection in the offshore zone is representative of resting.

The distribution of detections by seagrass bed stations and offshore stations, relative to the theoretical total number of possible detections if turtles were always detected by at least 1 station, is shown in Fig. 2. Detection of transmitters by the network of listening stations was generally high, although detection varied with both time (Fig. 2) and turtle (e.g. Turtle 4 vs. Turtle 6, Table 3). The majority of the seagrass bed detections ( 70 to $98 \%$ depending on the turtle) were obtained during the daytime, which clearly showed that turtles mainly exploited the seagrass bed during the day. In general, turtles grazed every day. They usually arrived on the seagrass bed around 06:00 h, sometimes earlier (e.g. Turtle 1, first peak at 04:00 h), and left around 18:00 h. Some night time detections were collected on

Table 2. Chelonia mydas. Distribution of detections received for each turtle (\% of detections) at seagrass stations (Stns 1 to 3) and offshore stations (Stns 4 and 5), and total number of detections received by each station during the $31 \mathrm{~d}$ study period from June 14 to July 14, 2003

\begin{tabular}{|c|c|c|c|c|c|}
\hline \multirow[t]{2}{*}{ Turtle } & \multicolumn{3}{|c|}{$\begin{array}{l}\text { Seagrass bed stations: } \\
\text { foraging activity }\end{array}$} & \multicolumn{2}{|c|}{$\begin{array}{l}\text { Offshore stations: } \\
\text { resting activity }\end{array}$} \\
\hline & Stn 1 & Stn 2 & Stn 3 & Stn 4 & Stn 5 \\
\hline 1 & 7.4 & 92.6 & 0.0 & 45.5 & 54.5 \\
\hline 4 & 7.3 & 92.7 & 0.1 & 14.1 & 85.9 \\
\hline 5 & 1.8 & 98.1 & 0.1 & 72.5 & 27.5 \\
\hline 6 & 14.8 & 84.6 & 0.6 & 65.8 & 34.2 \\
\hline 7 & 4.7 & 95.1 & 0.3 & 61.5 & 38.5 \\
\hline 8 & 3.8 & 96.2 & 0.1 & 15.8 & 84.2 \\
\hline Total & 1290 & 16944 & 31 & 13413 & 18572 \\
\hline
\end{tabular}

the seagrass bed (see Turtles 1, 5, 6 and 7) (Fig. 2). Detections by the stations located on the inner slope showed some interesting differences. While the numbers of detections during the night at these stations were higher than during the day for Turtles 1, 4, 7 and 8 , Turtles 5 and 6 did not show the same pattern. Turtle 6 was poorly detected by the offshore stations (Fig. 2).

\section{Influence of tides on signal reception by seagrass bed listening stations}

Fig. 3 represents the hourly emergence rate of the seagrass bed listening stations according to the time of day during the $31 \mathrm{~d}$ study period. Large tides were unequally distributed with respect to time of day (Fig. 3). The lowest tides occurred mainly around 10:00 and 11:00 $\mathrm{h}$; this period corresponds to a lack of detections for most of the turtles during the daytime (Fig. 2). Particularly low tides also appeared with high frequency around 22:00 to 23:00 h, but no clear loss of detections during this period was observed.

\section{Influence of the night light on foraging behaviour}

The numbers of night hours when the moon was present in the sky (189 h) and when it was absent (195 h) were quite similar during the study period. The seagrass bed listening stations (1,2 and 3) recorded a total of 1319 turtle detections during times when the moon was present, and 635 when it was absent. The difference between the hourly mean number of detections showed that turtles foraged on the seagrass bed during the night more often when the moon was present (6.97 detections $\mathrm{h}^{-1}$ ) than when it was absent (3.26 detections $\mathrm{h}^{-1}$ ). The number of detections per night and the night light index (moon light intensity and cloudiness) were positively correlated $(\mathrm{r}=0.54, \mathrm{p}=0.002$ ) (Fig. 4). However, a detailed examination of Fig. 4 shows that for similarly high values of moon light index at the beginning and end of the study period, we obtained different results in terms of number of detections. While turtles were foraging during the night at the

Table 3. Chelonia mydas. Percentage of detections of the expected number of total detections for each green sea turtle and for each hour of the day over the $31 \mathrm{~d}$ study period from June 14 to July 14,2003

\begin{tabular}{|lrcccrr|}
\hline Turtle & 1 & 4 & 5 & 6 & 7 & 8 \\
\hline Maximum & 52 & 76 & 40 & 48 & 74 & 61 \\
Minimum & 9 & 35 & 16 & 1 & 7 & 9 \\
Average & 33 & 54 & 25 & 20 & 36 & 43 \\
\hline
\end{tabular}




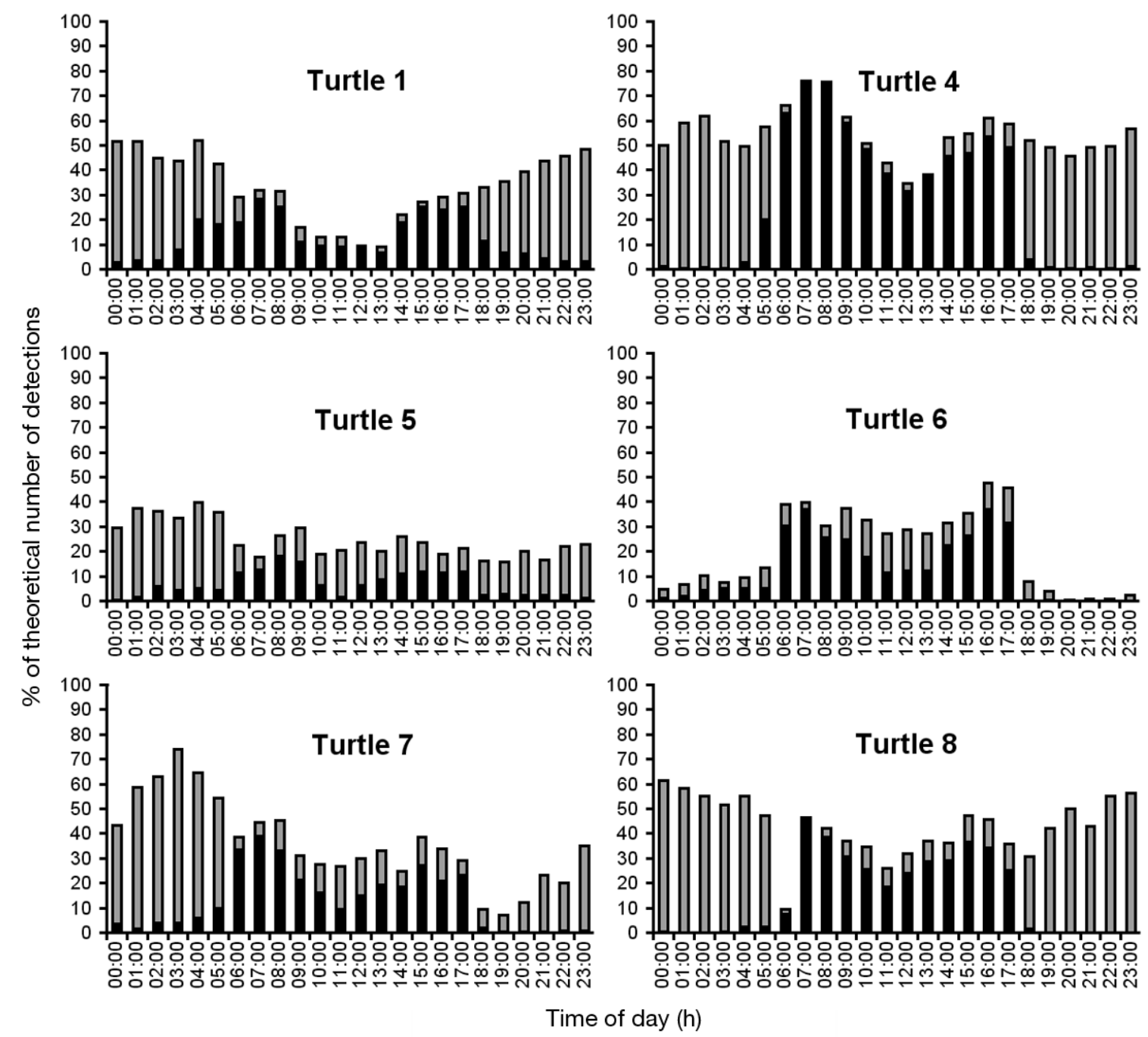

Fig. 2. Percentages of seagrass (black) and offshore detections (grey) of the expected number of total detections, according to time of day for each tagged turtle tracked over the $31 \mathrm{~d}$ period from June 14 to July 14, 2003

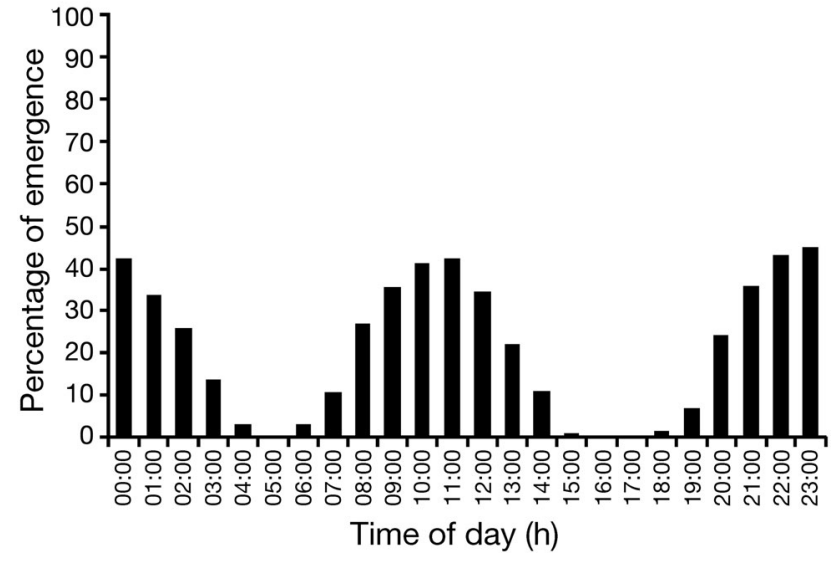

Fig. 3. Estimated percentage of the total time that listening Stns 1,2 and 3 on the seagrass bed were emerged (due to low tides) for each hour of the day over the $31 \mathrm{~d}$ period from June 14 to July 14, 2003 beginning of the study, they did not exhibit the same pattern in similar night light conditions at the end. However, when the night light was very low in the middle of the study period, they were rarely detected on the seagrass during the night.

\section{DISCUSSION}

Experimental technique: ultrasonic transmitters and listening stations

The ultrasonic transmitters and listening stations used to track green sea turtles in this study have distinct advantages over many of the techniques used previously to determine foraging behaviour. Permanent listening stations allowed continuous monitoring of the behaviour of turtles whilst they were within 


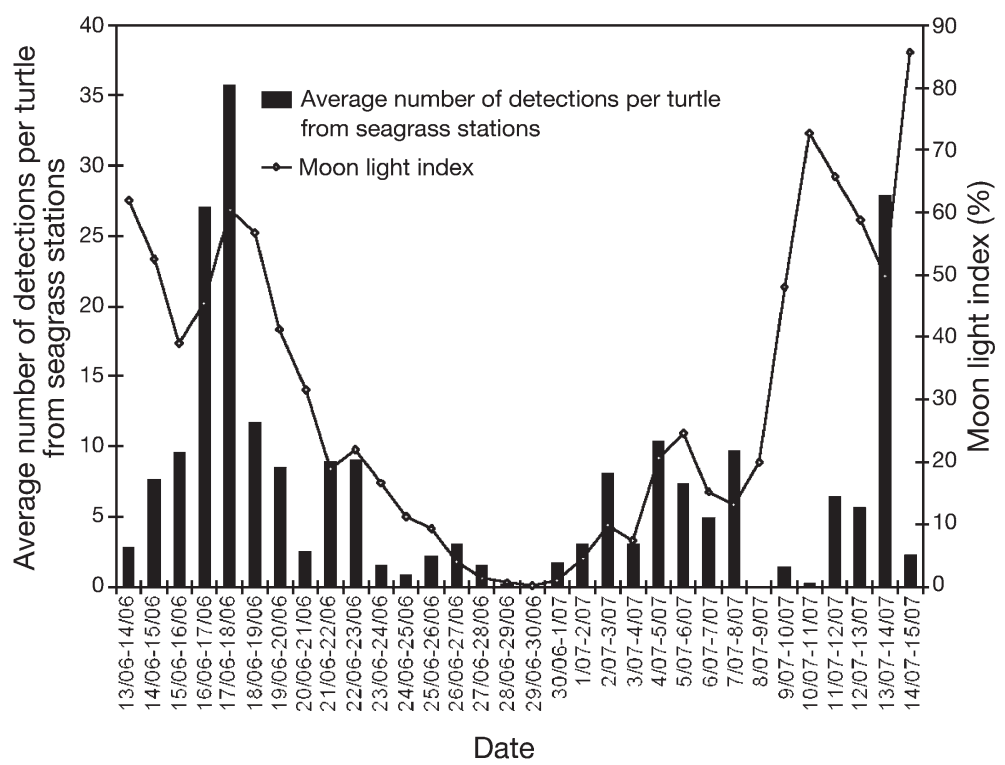

Fig. 4. Moon light index and average number of detections per turtle by the seagrass bed listening stations for each night of the $31 \mathrm{~d}$ study period from June 14 to July 14, 2003. Dates given as dd/mm

\section{Foraging behaviour of green sea turtles in N'Gouja Bay}

Although some turtles were observed more than others by the network of listening stations, they all exhibited the same diel pattern: they fed on the seagrass bed during the day, and rested on the inner slope during the night. Brill et al. (1995) found 2 different patterns for juvenile green sea turtles in Kaneohe Bay (Hawaii, USA): some fed during the day (like turtles observed during our research), while others fed at night. In this study, Turtles 1, 5, 6 and 7 fed during the night time on occasion, especially during the first part of the study when night light was high, but night time foraging behaviour was generally uncommon. We do not know why turtles did not feed during the night at the end of the study when night light was also high. Factors such as low tides at night combined with rough weather conditions may have affected water visibility and therefore grazing. Such conditions may have also caused partial emergence of the listening stations leading to a loss of detections. Seminoff et al. (2002) showed that the green turtles in Bahia Bay off Los Angeles spent significantly more time at depths of 10 to $30 \mathrm{~m}$ during the day and 0 and $10 \mathrm{~m}$ during the night, which contrasted with the patterns of depth use by turtles in this study. This difference in diel bathymetric behaviour may be explained by different configurations of the foraging sites rather than a difference in foraging rhythms.

Low tides during the middle of the day may account for the increased number of detections received by the offshore stations at the same time (mainly Turtles 5, 6 and 7; Fig. 2). The very shallow waters over the seagrass bed may have caused turtles to move to the inner slope for a few hours. Similarly, Limpus \& Limpus (2000) found low tides restricted access of green turtles to mangrove habitat in Queensland, Australia. However, such an increase in offshore detections was not observed for Turtles 1 and 4. They may have moved to offshore areas that were not covered by the listening stations, or remained on the seagrass bed and were not detected by the emerged listening stations. It is also possible that low tides were not the main factor responsible for this lack of data on the seagrass bed in the middle of the day. A resting phase at noon could also correspond to the intrinsic foraging rhythm of green turtles in N'Gouja Bay. The foraging pattern displayed by the immature turtle was similar to those of juvenile turtles at the US Virgin Islands (Ogden et al. 1983), with 2 feeding events during the day separated by a resting phase at noon. presence. 
Our results clearly demonstrated that turtles have a high affinity to specific areas of the seagrass bed in N'Gouja Bay, a behaviour already observed for green sea turtles in other areas (Whiting \& Miller 1998, BrandGardner et al. 1999, Seminoff et al. 2002), and that they need to spend a long time on the foraging grounds every day. The seagrass bed of N'Gouja Bay is relatively small ( 140 ha). During our dives we kept a minimum distance of $4 \mathrm{~m}$ from turtles to avoid disturbance; however, tourists may interact with turtles more closely. If turtles are sensitive to the presence of snorkelers or divers, increased activity of humans on this seagrass bed may alter their foraging success, with possible impacts on their behaviour and physiology. A turtle tagged with a conventional tag during its feeding phase in this study was later observed nesting on N'Gouja and Saziley beaches (K. Balbrain pers. comm.). It was the first time that these 2 behavioural phases have been observed at the same location in the southwest Indian Ocean for green turtles. This confirms that Mayotte Island is an exceptional site for all stages of green turtle life history and so must be protected. Long-term monitoring of turtles with acoustic tags and listening stations in coastal habitats should be encouraged, as it would enable examination of changes in foraging behaviour among seasons and years. Combined with data on environmental variables and human activities, this would also allow investigation into how turtle foraging behaviour changes with particular environmental conditions and human-generated disturbances.

Acknowledgements. Financial support was provided by the Fond Français pour l'Environnement Mondial (FFEM). Financial and technical support was also provided by the Agriculture and Forestry Administration of Mayotte. We thank C. Guillaume, Director of the Environment and Forestry Service (SEF) of Mayotte for support. The hotel 'Jardin Maoré' at N'Gouja generously provided us with accommodation. A. Mari and M. Quillard of SEF Turtle Team and members of the Oulanga Na Nyamba association provided technical assistance. Météo France Réunion kindly provided us with cloudiness data. Dr. S. Benhamou (CNRS Montpellier) provided useful comments on earlier versions of this manuscript.

\section{LITERATURE CITED}

Altmann J (1974) Observational study of behavior: sampling methods. Behaviour 49:227-267

Bjorndal KA (1991) Digestive fermentation in green turtles, Chelonia mydas, feeding on algae. Bull Mar Sci 48: 166-171

Bjorndal KA (1997) Foraging ecology and nutrition of sea turtles. In: Lutz PL, Musick JA (eds) The biology of sea turtles. CRC Marine Science Series, CRC Press, Boca Raton, FL, p 199-231

Brand-Gardner SJ, Lanyon JM, Limpus CJ (1999) Diet selection by immature green turtles, Chelonia mydas, in subtropical Moreton Bay, south-east Queensland. Aust J Zool 47:181-191

Editorial responsibility: Otto Kinne (Editor-in-Chief), Oldendorf/Luhe, Germany
Brill RW, Balazs GH, Holland KN, Chang RK, Sullivan S, George JC (1995) Daily movements, habitat use, and submergence intervals of normal and tumor-bearing juvenile green turtles (Chelonia mydas L.) within a foraging area in the Hawaiian islands. J Exp Mar Biol Ecol 185: 203-218

Cheng IJ (2000) Post-nesting migrations of green turtles (Chelonia mydas) at Wan-An Island, Penghu Archipelago, Taiwan. Mar Biol 137:747-754

Dizon AE, Balazs GH (1982) Radio telemetry of Hawaiian green turtles at their breeding colony. Mar Fish Rev 44: $13-20$

Frazier J (1985) Marine turtles in the Comoro Archipelago. North Holland Publishing, Amsterdam

Godley BJ, Richardson S, Broderick AC, Coyne MS, Glen F, Hays GC (2002) Long-term satellite telemetry of the movements and habitat utilisation by green turtles in the Mediterranean. Ecography 25:352-362

Guerniou A, Nicet JB (2001) Inventaire des herbiers marins du récif frangeant de Mayotte (côte ouest). Collectivité Territoriale de Mayotte, Direction de l'Agriculture et de la Forêt, Service des pêches et de l'environnement marin, Mamoudzou, Mayotte Island

Ireland LC (1981) Homing behavior of immature green turtles (Chelonia mydas). Proc Assoc Isl Mar Lab Caribb 16:7

Le Gall JY, Hughes GR (1987) Migrations de la tortue verte Chelonia mydas dans l'océan Indien Sud-Ouest observées à partir des marquages sur les sites de ponte Europa et Tromelin (1970-1985). Amphib Reptil 8:277-282

Le Gall JY, Chateau D, Bosc P (1985) Rythme de reproduction inter annuel des tortues vertes Chelonia mydas sur les sites de ponte Tromelin et Europa (océan Indien). CR Acad Sci Paris 5:195-200

Le Gall JY, Bosc P, Chateau D, Taquet M (1986) Estimation du nombre de tortues vertes femelles adultes Chelonia mydas par saison de ponte à Tromelin et Europa (océan Indien 1973-1985). Océanogr Trop 21:3-22

Limpus CJ, Limpus DJ (2000) Mangroves in the diet of Chelonia mydas in Queensland, Australia. Mar Turtle Newsl 89: $13-15$

Luschi P, Hays GC, Del Seppia C, Marsh R, Papi F (1998) The navigational feats of green sea turtles migrating from Ascension Island investigated by satellite telemetry. Proc R Soc Lond B 265:2279-2284

Mendonca MT (1983) Movements and feeding ecology of immature green turtles (Chelonia mydas) in a Florida lagoon. Copeia 4:1013-1023

Ogden JC, Robinson L, Whitlock K, Daganhardt H, Cebula R (1983) Diet foraging patterns in juvenile green turtles (Chelonia mydas) in St. Croix United States Virgin Islands. J Exp Mar Biol Ecol 66:199-205

Pelletier D, Roos D, Ciccione S (2003) Oceanic survival and movements of wild and captive-reared immature green turtles (Chelonia mydas) in the Indian Ocean. Aquat Living Resour 16:35-41

Seminoff JA (2004) Chelonia mydas. 2004 IUCN Red List of Threatened Species, available at www.iucnredlist.org

Seminoff JA, Resendiz A, Nichols WJ (2002) Home range of green turtles Chelonia mydas at a coastal foraging area in the Gulf of California, Mexico. Mar Ecol Prog Ser 242: 253-265

Taquet M (2004) Le comportement agrégatif de la dorade coryphène (Coryphaena hippurus) autour des objets flottants. PhD thesis, University of Paris 6

Whiting SD, Miller JD (1998) Short term foraging ranges of adult green turtles (Chelonia mydas). J Herpetol 32: $330-337$

Submitted: December 9, 2004; Accepted: July 19, 2005

Proofs received from author(s): November 29, 2005 